\title{
Originals
}

\section{Influence of affinity of antibodies upon their detection by liquid phase radiobinding assay and solid phase enzyme linked immunosorbent assay. Demonstration using monoclonal antibodies raised against rDNA human proinsulin}

\author{
J.C.Sodoyez ${ }^{1}$, M.Koch ${ }^{2}$, I.Lemaire ${ }^{2}$, F.Sodoyez-Goffaux ${ }^{2}$, A. Rapaille ${ }^{3}$, Ch. François-Gérard ${ }^{3}$ and D.Sondag $^{3}$ \\ ${ }^{1}$ Department of Endocrinology, ${ }^{2}$ Division of Nuclear Pediatrics and \\ ${ }^{3}$ Department of Blood Transfusion, CHU - Sart Tilman, University of Liege, Liege, Belgium
}

\begin{abstract}
Summary. Hybridomas producing proinsulin antibodies were cloned by limiting dilution of cell cultures obtained by fusion of splenocytes of immunized mice with immortal myeloma cells. Some proinsulin monoclonal antibodies crossreacted with labelled insulin but none did with labelled C-peptide indicating that the involved epitopes were at one of the insulin/C-peptide junctions or included in the insulin moiety. Hybridoma supernatants were assayed for $\mathrm{IgG}$ concentration by a solid phase assay and for ligand binding by a radiobinding assay and an enzyme linked immunosorbent assay. The half-life of immune complexes formed with radioligand was measured and, as expected, correlated with affinity as measured by the method of Scatchard. Antibody titres determined by enzyme linked immunosorbent assay did not correlate to those measured by radiobinding assay.
\end{abstract}

IgG concentration correlated to enzyme linked immunosorbent assay titres but not to radiobinding assay titres. Finally, a significant correlation was found between radiobinding assay titre and the product of enzyme linked immunosorbent assay titre by the period of immune complexes. It is concluded that, except for very low affinity antibodies, enzyme linked immunosorbent assay is a capacity assay whereas radiobinding assay is influenced by both antibody concentration and affinity. The former assay is thus best suited to detecting low affinity antibodies whereas the latter is more efficient in the presence of low levels of high affinity antibodies.

Key words: Proinsulin monoclonal antibodies, affinity, solidliquid phase assay, radiobinding assay.
Insulin antibodies which circulate in diabetic patients treated with insulin are easily detectable by radiobinding assay (RBA) as well as by solid phase assay (ELISA). Yet, even in these circumstances where the level of antibodies is usually high, agreement between the measurements of insulin antibodies by the two techniques is rated differently, some authors finding a good correlation [1], others finding no correlation [2]. Several explanations for these discrepancies have been proposed. Firstly, in the solid phase assay, insulin molecules may be systematically adsorbed by the same surface which therefore becomes unavailable for antibody binding. By extension, coating of insulin may partially denature the molecule and prevent some populations of antibodies from binding to distorted epitopes [3]. In the hands of others, the hypothesis of hidden or distorted epitopes proved an unsatisfactory explanation for all the discrepancies between RBA and ELISA results [2, 4]. Secondly, the presence of radioactive iodine on insulin alters the surface of the molecule and may modify the binding affinity of complementary molecules, be they insulin receptors [5, 6] or insulin antibodies [2]. Although it does occur, this phenomenon does not explain all the dif- ferences between the two assay systems. Thirdly, the influence of affinity of the antibody for its ligand may be different in the two types of assay $[7,8]$.

If both assays give positive signals in diseases characterized by a high level of plasma antibodies such as insulintreated diabetes mellitus [9], insulin autoimmune syndrome [10-15] and certain drug reactions [16-18], they may respond in the opposite manner in cases where the level of circulating antibodies are low such as in the normal population [19-21], in Type 1 (insulin-dependent) diabetes at onset [22-27] or in relatives of Type 1 diabetic patients, either unaffected twins [28] or siblings [29]. It therefore becomes important to understand better the basic mechanisms of both assays in order to select the most appropriate for the purpose. This type of study is not feasable on polyclonal serum containing several populations of antibodies of different affinity and epitope specificity. We therefore raised a panel of monoclonal antibodies against proinsulin, characterized them regarding immunoglobulin concentration and affinity for their ligand and compared their behaviour in the two assay systems. 


\section{Materials and methods}

\section{Preparation of monoclonal antibodies against human proinsulin}

Hybridomas were produced from spleen lymphocytes of mice immunized with rDNA human proinsulin. Briefly, BALB/c or Biozzi mice were injected $i$. p. with $20 \mu \mathrm{g}$ proinsulin formulated in complete Freund adjuvant. The mice received additional injections at $2-$ 3 week intervals of the same amount of proinsulin emulsified in incomplete Freund adjuvant. They were screened by RBA for proinsulin antibodies 10 days later and the animals with the highest titres were selected for fusion. One to two months after the third injection, they received a booster of $20 \mu \mathrm{g}$ proinsulin without adjuvant and, 4 days later, their spleens were aseptically dissected out. After collection in RPMI medium, the splenocytes were fused with SP2/0 myeloma cells as previously described [30]. Fused cells were then transferred to 96 -well plates containing naive mouse peritoneal macrophages as feeders in hypoxanthine-aminopterine-thymidine (HAT) medium supplemented with $10 \%$ fetal calf serum (FCS). After 1 week of culture, the HAT medium was replaced by hypoxanthine-thymidine (HT) medium containing $10 \%$ FCS. After cell proliferation, the supernatant of the cell cultures was screened for antibodies and the antibody producing hybridomas were cloned by limiting dilutions in HT medium supplemented with $10 \%$ FCS and $5 \%$ human umbilical cord serum [31]. Monoclonal antibodies were tested with ${ }^{125} \mathrm{I}$-labelled insulin and C-peptide in order to define the molecule moiety containing the epitope. Some fully crossreacted with insulin, none crossreacted with C-peptide. Involved epitopes were therefore either included in the insulin moiety for the insulin crossreacting antibodies or located at one of the insulin-C-peptide junction for the non-crossreacting antibodies.

\section{Measurement of IgG concentration in mouse hybridoma culture supernatants}

IgG concentration in the mouse hybridoma culture supernatants was measured by a solid phase assay [32]. Briefly, immunoplates were coated overnight at $4^{\circ} \mathrm{C}$ with $100 \mu \mathrm{l}$ of a solution of purified rat monoclonal antibody directed against mouse IgG $\mathrm{K}$ light chain $(25 \mu \mathrm{g} / \mathrm{ml}$ LO-MK-2, Experimental Immunology Unit, UCL, Louvain $\mathrm{La}$ Neuve, Belgium) in $0.1 \mathrm{~mol} / \mathrm{l}$ bicarbonate buffer, $\mathrm{pH} 9.6$. After washing with distilled water, the remaining sites were saturated with $250 \mu \mathrm{l}$ phosphate buffer containing $0.5 \%$ bovine serum albumin and $0.1 \%$ Tween 20 . Fifty microliters of serial two-fold dilutions of the mouse hybridoma culture supernatants (starting dilution 1/1000) and mouse immunoglobulin reference serum (starting dilution 1/5000; ICN immunobiologicals, Lisle, Ill., USA), were added to the coated wells and incubated for $2 \mathrm{~h}$ at $37^{\circ} \mathrm{C}$. After washing with distilled water, $50 \mu \mathrm{l}$ rat monoclonal antibody against mouse $\mathrm{K}$ light chain conjugated to peroxidase (LO-MK-1 peroxidase, Experimental Immunology Unit) was added to the wells and incubated for $2 \mathrm{~h}$ at $37^{\circ} \mathrm{C}$. After washing with distilled water, $50 \mu$ of the $\mathrm{H}_{2} \mathrm{O}_{2}-$ chromogen solution was added $(5 \mathrm{mg} / \mathrm{ml}$ O-phenylene diamine (Abbot Laboratories, Wiesbaden, FRG), $0.003 \% \mathrm{H}_{2} \mathrm{O}_{2}$ in $0.1 \mathrm{~mol} / \mathrm{l}$ citrate-phosphate buffer, $\mathrm{pH} 5.5$ ). The reaction was stopped $15 \mathrm{~min}$ later by addition of $100 \mu 12 \mathrm{~N} \mathrm{H}_{2} \mathrm{SO}_{4}$ and optical density at $492 \mathrm{~nm}$ was measured. A blank was included in the first well of each row to quantify non-specific binding of the immunoconjugate.

\section{Enzyme linked immunosorbent assay for proinsulin antibodies}

Titres of anti proinsulin monoclonal antibodies were measured using a modification of a previously described method [33]. Briefly, $75 \mu \mathrm{l}$ of $13.3 \mu \mathrm{g} / \mu \mathrm{l}$ proinsulin in carbonate-bicarbonate coating buffer $\mathrm{pH} 9.6$ were aliquoted in the wells of microtitre plates (NUNC, $n^{\circ} 4-39454$, Gibco, Paisley, UK). After overnight incubation at $4^{\circ} \mathrm{C}$, the plates were washed three times with phosphate buffered saline (PBS), $0.5 \%$ Tween $20,0.2 \%$ bovine serum albumin $\mathrm{pH} 7.2$ and allowed to stand for $30 \mathrm{~min}$ at room temperature in order to saturate the remaining polystyrene reactive sites. The wells were then refilled with serial twofold dilutions of the monoclonal antibodies, the first well of each row receiving buffer alone and serving as a blank. After $2 \mathrm{~h}$ incubation at $37^{\circ} \mathrm{C}$ and three successive washes, all the wells were refilled with $50 \mu \mathrm{l}$ of a 1/250 dilution of rabbit anti-mouse immunoglobulin serum conjugated to peroxidase (HRP-RAM-Ig, P260, Dakopatts, Glostrup, Denmark). After $1 \mathrm{~h}$ incubation at $37^{\circ}$ followed by four washes with tap water, the assay was developed by adding $50 \mu \mathrm{l}$ of ABTS solution $\left(2.2^{\prime}\right.$ - azino-di-3 ethylbenzthiazolinosulfat $6,75 \mathrm{mg} / 100 \mathrm{ml}$, Boehringer, Mannheim, FRG) containing $\mathrm{H}_{2} \mathrm{O}_{2}(0.004 \%$ volume/volume). The reaction was finally stopped $30 \mathrm{~min}$ later by the addition of $150 \mu \mathrm{l} 2 \mathrm{~N} \mathrm{H}_{2} \mathrm{SO}_{4}$ and absorbance was read at $405 \mathrm{~nm}$ using a multichannelspectrophotometer (LP-200, Institut Pasteur, Paris, France).

\section{Radiobinding assay ( $R B A$ ) for proinsulin antibodies}

RBA was performed using reverse phase HPLC purified Tyr A14 monoiodinated $\left[{ }^{125} \mathrm{I}\right]$ proinsulin of specific activity $200-233 \mu \mathrm{Ci} / \mu \mathrm{g}$ or, for the $100 \%$ crossreacting antibodies, Tyr A14 monoiodinated $\left.{ }^{125} \mathrm{I}\right]$ insulin of specific activity $300-350 \mu \mathrm{Ci} / \mu \mathrm{g}$ [34-35]. Briefly, a constant amount of radioligand $(20,000 \mathrm{cpm}$ in $100 \mu \mathrm{l})$ was mixed with duplicate $100 \mu \mathrm{l}$ samples of several two-fold monoclonal antibody dilutions in serum pre-treated with dextran-coated charcoal. After an overnight incubation at $4{ }^{\circ} \mathrm{C}, 1 \mathrm{ml}$ of $18 \%$ (weight/volume, w/v) polyethylene glycol (PEG) 6000 (Fluka, Buchs, Switzerland) was added to each tube. After $15 \mathrm{~min}$ at room temperature, the tubes were centrifuged, supernatants were discarded, precipitates were washed with $1 \mathrm{ml} \mathrm{PEG} 15 \%(\mathrm{w} / \mathrm{v})$ and their radioactivity was measured using a multi-well gamma counter (Berthold LB 2101, Wildbad, FRG). The percentage of antibody-bound radioligand was calculated as the percentage of radioactivity of the precipitate. Blank values obtained by substituting serum free for monoclonal antibody solution were subtracted from sample values.

\section{Dissociation of immune complexes formed at the solid-liquid phase interface}

Four different monoclonal antibodies were tested on proinsulin coated plates. The wells received $50 \mu \mathrm{l}$ of serial two-fold dilutions of each monocional and after $2 \mathrm{~h}$ incubation at $37^{\circ} \mathrm{C}$ and three washes, were refilled with $50 \mu \mathrm{l}$ PBS with or without a large excess $(400 \mu \mathrm{g} / \mathrm{ml})$ proinsulin. The plates were incubated at $4^{\circ} \mathrm{C}$ for 24,48 or $96 \mathrm{~h}$. After aspiration of the liquid phase and three washes, the wells successively received, as described above, rabbit anti-mouse immunoglobulin serum conjugated with peroxidase followed by ABTS$\mathrm{H}_{2} \mathrm{O}_{2}$ and stopping solution and absorbance at $405 \mathrm{~nm}$ was recorded.

In order to differentiate true dissociation of immune complexes from desorption of coated ligand, the desorption rate of radiolabelled ${ }^{125}$ I-proinsulin was estimated. Microplates were coated as described above except that in addition to native proinsulin, the coating solution also contained Tyr A14 monoiodo [ $\left.{ }^{125} \mathrm{I}\right]$ proinsulin. The wells were filled with $50 \mu \mathrm{l}$ buffer and left at 4 or $37^{\circ} \mathrm{C}$. The liquid phase was withdrawn $0,1,4,24$ and $48 \mathrm{~h}$ later and the radioactivity counted and expressed as a percentage of the initial coated activity ( $14 \%$ of the radioactivity added in the coating solution).

\section{Dissociation of immune complexes formed by radioligand in liquid phase}

Immune complexes were formed by an overnight incubation of monoclonal antibodies with ${ }^{125} \mathrm{I}$ radioligand $(20,000 \mathrm{cpm})$. At the start of the dissociation experiment, an excess of native ligand $(10 \mu \mathrm{g}$ 


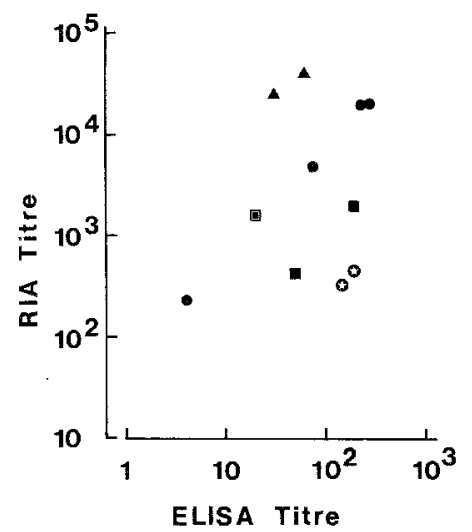

Fig. 1. Correlation between titres of hybridoma culture supernatants determined by radiobinding assay (RBA) and enzyme linked immunosorbent assay (ELISA). Eleven culture supernatants corresponding to at least five different monoclonal antibodies originating from four different fusions were studied: $\mathrm{D}=\mathrm{F} 65(n=1), \boldsymbol{\Delta}=\mathrm{S} 1(n=2)$, $=\$ 2$ (species $100 \%$ crossreacting with insulin and proinsulin, $n=2$ ) $0=\mathrm{S} 2$ (proinsulin specific species, $n=4), \square=\mathrm{S} 3$ $(n=2)$

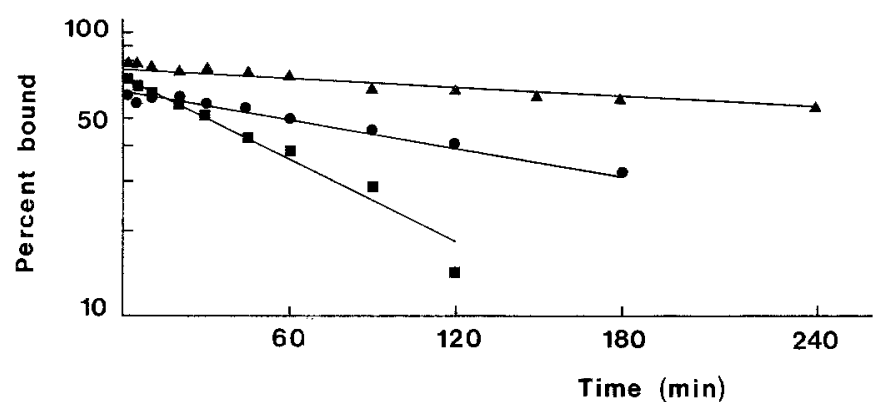

Fig. 2. Dissociation rate of immune complexes in homogeneous liquid phase. $\boldsymbol{\Delta}=\mathrm{S} 1, \mathbf{O}=\mathrm{S} 2$ (proinsulin specific species) and $=S 3$. The equation $A_{t}=A_{o} \varepsilon^{-\lambda t}$ where $A_{t}$ and $A_{o}$ are the amounts of immune complexes at times 0 and $t, \lambda$, is the dissociation rate and $t$, the time, was used to calculate the half-life ( $T$ ) of the immune complexes

in $1 \mathrm{ml}$ ) was added, duplicate aliquot samples were drawn at selected times and immediately precipitated by $1 \mathrm{ml} \mathrm{PEG} 18 \% \mathrm{w} / \mathrm{v}$. After centrifugation and elimination of the supernatant, the radioactivity of the pellet was measured and expressed as a percentage of the total.

\section{Measurement of affinity constant}

Affinity constants of the various monoclonal antibodies was measured using the method of Scatchard [36]. Each monoclonal was diluted so as to bind $60 \%$ of the radioactive tracer $(20,000 \mathrm{cpm})$ after a 4 day incubation at $4^{\circ} \mathrm{C}$ in the absence of added native ligand. Duplicate samples of this monoclonal antibody dilution received a constant amount of radioligand $(20,000 \mathrm{cpm}$ in $100 \mu \mathrm{l})$ and $100 \mu \mathrm{l}$ buffer alone or containing increasing concentrations of competitor (from $2.07 \times 10^{-11}$ to $\left.1.4 \times 10^{-7} \mathrm{~mol} / \mathrm{l}\right)$. After 4 days incubation at $4^{\circ} \mathrm{C}$, immune complexes were precipitated by $P E G$ and their radioactivity measured. After subtraction of the non-specific binding measured on samples containing a large excess of native ligand $(10 \mu \mathrm{g} / \mathrm{ml})$, results were plotted as bound/free antigen ratio vs bound antigen.

\section{Results}

For each of the 11 monoclonal antibodies, titres of culture supernatants were determined by solid and liquid phase assays. The reciprocal of the monoclonal antibody dilution corresponding to $1.0 \mathrm{U}$ of optical density was taken as the ELISA titre and that corresponding to $50 \%$ radioligand binding was taken as the RBA titre. As illustrated in Figure 1, there was no correlation between the two sets of titres $\left(r^{2}=0.019, p>0.3\right)$.

As shown in Figure 2, preformed immune complexes made with monoclonal antibodies and radioligand dissociated in a semi-logarithmic fashion. The half-life (T) of the immune complexes was calculated (Table 1) and found to range from 30 to $570 \mathrm{~min}$.

The affinity constant of 9 of the same 11 monoclonal antibodies was determined by Scatchard analysis. All Scatchard plots were linear. Individual values of affinity and the coefficients of correlation for linearity of the Scatchard plots are listed in Table 1 . As expected, a highly significant correlation existed between the half-life of the immune complexes and affinity as measured by Scatchard analysis $\left(\mathrm{y}=4.92 \times 10^{-9}+31 ; n=9 ; r^{2}=0.930 ; p<0.005\right)$.

Before measuring the dissociation rate of immune complexes formed in solid phase between the coated ligand and the soluble monoclonal antibody, we estimated the desorption rate of the coated ligand. Assuming that the rate of desorption of radioligand is the same as that of the native one, we measured that, even after 2 days at $37^{\circ} \mathrm{C}$, less than $2 \%$ of the coated ligand returned to the liquid phase (Table 2). This percentage was considered as negligible and no correction for spontaneous desorption was made for the dissociation experiments.

Table 1. Properties of 11 monoclonal antibodies against human proinsulin

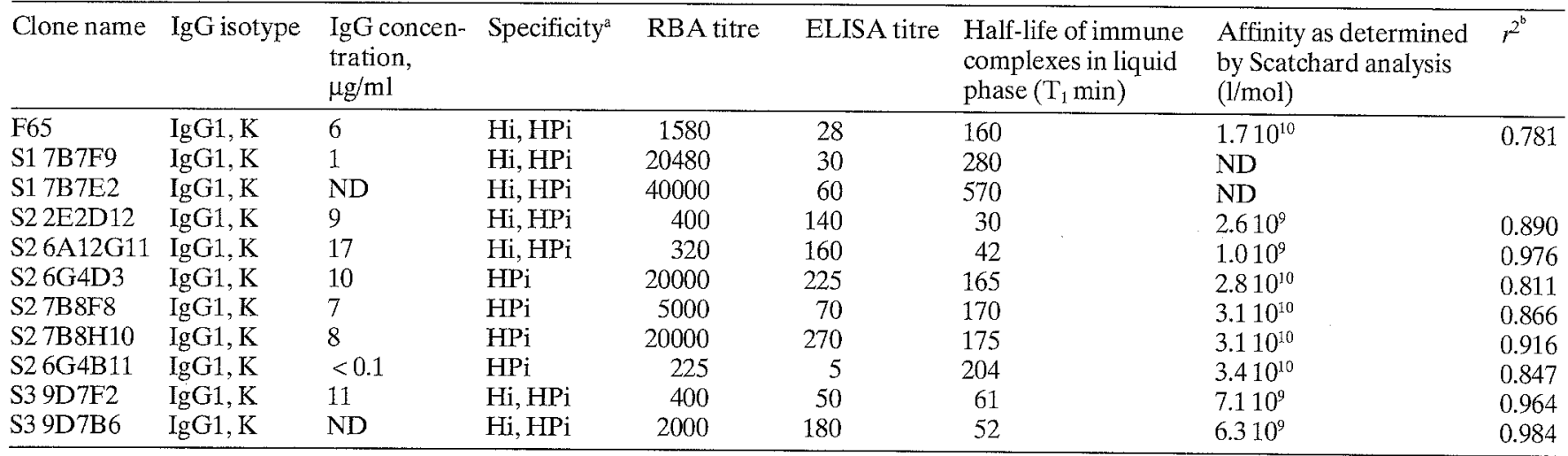

${ }^{a} \mathrm{Hi}, \mathrm{HPi}: 100 \%$ crossreactivity for $\mathrm{Hi}$ and $\mathrm{HPi}$; HPi: no crossreactivity with either insulin or C-peptide; ${ }^{b}$ Coefficient of correlation for linearity of Scatchard plot.

$\mathrm{RBA}=$ Radiobinding assay 


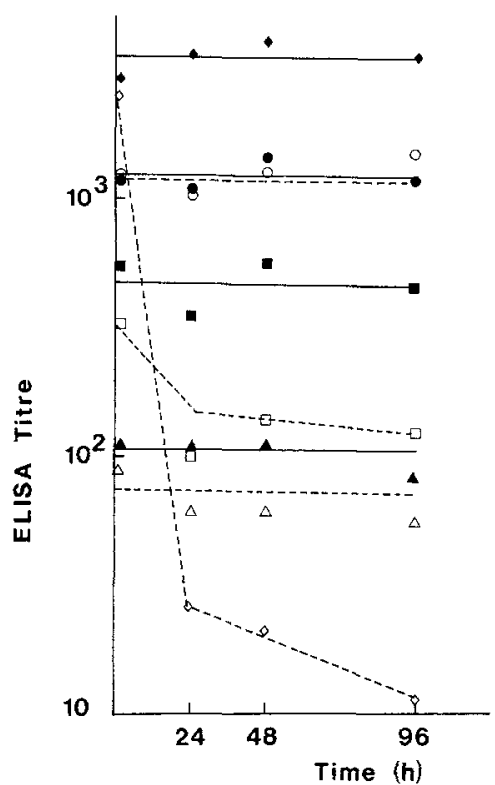

Fig.3. Dissociation rate of immune complexes in heterogeneous liquid-solid phase, in the absence (closed symbols, solid lines) or the presence (open symbols, dashed lines) of excess native ligand. $\boldsymbol{\Delta}=\mathrm{S} 1, \boldsymbol{O}=\mathrm{S} 2$ (proinsulin specific species), $\boldsymbol{\square}=\mathrm{S} 3$ and $\bullet=\mathrm{S} 8$. ELISA = enzyme linked immunosorbent assay

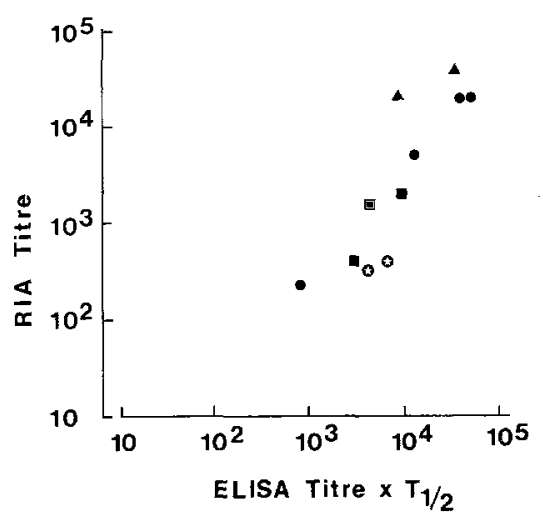

Fig.4. Correlation between radiobinding assay (RBA) titres and the product of enzyme linked immunosorbent assay (ELISA) titres by half-life of immune complexes of the same 11 hybridoma culture supernatants as in Figure 1. Same symbols as in legend of Figure 1

As shown by Figure 3, immune complexes formed at the solid-liquid interface did not significantly dissociate after 4 days incubation in the absence of added native ligand. This held true even for clone S8 which, in liquid phase, formed very unstable immune complexes characterized by a dissociation period of less than $1 \mathrm{~min}$. By contrast, in the presence of an excess of native ligand, dissociation became significant for clone $\mathrm{S} 8$. A mild dissociation was observed for clone $S 3$ ( $T$ in liquid phase $=60 \mathrm{~min}$ ) and no effect whatsoever was discernable for clones $\mathrm{S} 1$ and $\mathrm{S} 2$ (respective $\mathrm{T}$ in liquid phase $=570 \mathrm{~min}$ for $\mathrm{S} 1$ and $170 \mathrm{~min}$ for S2). As shown by Figure 4, when RBA titres were plotted against a parameter integrating antibody concentration and affinity such as the product of ELISA titre by the period of immune complexes, a highly significant correlation was found $\left(r^{2}=0.93, p<0.005\right)$.
Table 2. Percent of desorption of ${ }^{125} \mathrm{I}$-Tyr A14 human insulin

\begin{tabular}{rllll}
\hline & $1 \mathrm{~h}$ & $4 \mathrm{~h}$ & $24 \mathrm{~h}$ & $48 \mathrm{~h}$ \\
\hline $4^{\circ} \mathrm{C}$ & 0.2 & 0.3 & 0.7 & 0.8 \\
$37^{\circ} \mathrm{C}$ & 0.5 & 0.4 & 0.9 & 1.1 \\
\hline
\end{tabular}

\section{Discussion}

As already mentioned, using polyclonal insulin antibodies developed in insulin-treated diabetic patients, we did not find any correlation between antibody titres determined by both assays [2]. This observation is now confirmed using monoclonal antibodies.

A major difference between the two assays lies in the fact that RBA follows the law of mass action and that, in view of the low concentration of ligand $(0.06 \mathrm{ng} / \mathrm{tube})$, formation of immune complexes is strongly dependent upon affinity of the antigen-antibody reaction. Although indirect evidence supported this contention, no direct proof could be provided because of the impossibility to measure affinity of a polyclonal immune serum, which yields curvilinear dissociation curves and Scatchard plots. By contrast, monoclonal antibodies which, in liquid phase, provided mono exponential dissociation curves and linear Scatchard plots allowed straightforward measurements of affinity. In liquid phase, the association rate depends upon physical parameters such as size of the ligand and thermal agitation whereas the dissociation rate rather reflects the structural complementarity between the epitope and the paratope. The relationship between affinity $(\mathrm{K})$ and halflife of immune complexes $(T)$ is shown by the equation:

$\mathrm{K}=\frac{\mathrm{Ka}}{0.678} \mathrm{~T}$

$\mathrm{K}=$ affinity, $\mathrm{K}_{\mathrm{a}}=$ association constant, $\mathrm{T}=$ half-life of immune complexes. The association constant $\mathrm{K}_{\mathrm{a}}$ may be defined by the equation $\mathrm{K}_{\mathrm{a}}=\mathrm{A} \varepsilon^{-\mathrm{Ea} / \mathrm{RT}}$ where $\mathrm{A}$ is a frequency factor, $\mathrm{Ea}$ is the energy of activation, $\mathrm{R}$ is the molar gas constant and $\mathrm{T}$ the absolute temperature [37].

The association constant directly depends on the diffusion rate and is comparable for all antigen-antibody reactions, ranging from $10^{7}-10^{8} \mathrm{~mol}^{-1}$ for haptens to $10^{5}-10^{6} \mathrm{~mol}^{-1}$ for protein antigens [38]. As expected from these thermodynamic considerations, a statistically significant correlation was found between the half-life of the immune complexes and the affinity constant measured by Scatchard analysis. Therefore, both parameters allow ranking of the antibodies according to affinity.

In the solid phase assay, a much greater amount of ligand $(140 \mathrm{ng})$ is coated on the wall of the wells [33]. Therefore, in ELISA, proinsulin or insulin locally achieve extremely high densities thereby conferring to this assay a very low degree of sensitivity to affinity. This is indeed proved by the fact that monoclonal antibodies of extremely low affinity ( $\mathrm{T}$ of immune complexes in liquid phase $<1 \mathrm{~min}$ ) form stable immune complexes at the solid-liquid interface. Addition of an excess of native ligand had no apparent effect on the dissociation of coated ligand-monoclonal antibody immune complexes except 
when the affinity of the antibody was low or very low. This is taken as evidence that dissociation does occur in the solid phase assay but to a negligible extent for antibodies of high affinity $\left(10^{8}-10^{10}\right)$ and to increasing extent when affinity decreases. Thus, when antibodies of high affinity are assayed, ELISA is insensitive to affinity and the final optical density signal merely reflects antibody concentration (C). As seen above, the RBA signal is a biparametric variable depending not only upon antibody concentration (C) but also upon antibody affinity $(\mathrm{K})$. It therefore comes as no surprise that no correlation exists between ELISA and RBA titres as there is no proportionality between C alone and the product $\mathrm{CK}$ whereas a significant correlation exists between the RBA titre and a parameter integrating antibody concentration and affinity such as the product of ELISA titre by the period of immune complexes. Furthermore, a significant correlation also existed between ELISA titres and IgG concentration $\left(r^{2}=0.73\right.$ $p<0.005, n=9$ ) whereas RBA titres and IgG concentration did not correlate $\left(r^{2}=0.02, p>0.20, n=9\right)$.

The hypothesis that the window in which ELISA is sensitive to affinity is much lower than that of RBA also accounts for the observation that autoantibodies with low affinity for insulin such as those found in the normal population are detectable by ELISA only and not at all by RBA [21]. It may further be implied that the ratio of RBA/ELISA titres is a function of affinity. Therefore, it becomes easily conceivable that a small amount of high affinity antibodies be detectable mostly or even exclusively by RBA. This could explain the much greater efficiency of RBA to detect insulin autoantibodies in Type 1 diabetic patients before onset of insulin therapy [39].

In conclusion, RBA and ELISA for insulin antibodies rely on markedly different thermodynamic reactions, the former being exquisitely sensitive to affinity, the latter being a capacity assay in the upper range of affinity and becoming sensitive to affinity only in the lower range of affinity. This hypothesis explains why both assays give a positive signal in the presence of a high concentration of antibodies such as in insulin-treated diabetes but that no correlation exists between the titres determined by the two assays. Very low affinity antibodies will be detectable by ELISA only whereas, on the contrary, small amounts of high affinity antibodies may be preferentially detected by RBA. As previously reported, because it is a capacity assay, ELISA may be standardised whereas, being a biparametric assay, RBA does not lend itself to standardisation using a reference serum [8].

Acknowledgements. rDNA human proinsulin was a generous gift of Dr. B.Frank, E. Lilly and Co., Indianapolis, Ind., USA. This work was supported by grants from the Fonds de la Recherche Scientifique Médicale (Brussels, Belgium). The secretarial assistance of Mrs. M. Hoste-Fodor is gratefully acknowledged.

\section{References}

1. Wilkin TJ (1986) The measurement of insulin antibodies and its interpretation in immunoassay technology. In: Pal SP (ed) Immunoassay technology vol 2. De Gruyter, New York, pp 17-56

2. Sodoyez-Goffaux F, Koch M, Dozio N, Brandenburg D, Sodoyez J-C (1988) Advantages and pitfalls of radioimmune and enzyme linked immunosorbent assays of insulin antibodies. Diabetologia 31: 694-702

3. Arquilla ER, Edwards S, McDougall BR, Mosqueda L, Stenger DP (1989) Differences in humoral insulin-antibody response among inbred Lou/m rats and epitope presentation differences in ELISA and radioimmune titration. Diabetes 38: 868-873

4. Nell LJ, Virta VJ, Thomas JW (1985) Application of a rapid enzyme-linked immunosorbent microassay (ELISA) to study human anti-insulin antibody. Diabetes 34: 60-66

5. Gliemann J, Sonne O, Linde S, Hansen B (1979) Biological potency and binding affinity of monoiodoinsulin with iodine in tyrosine A14 or tyrosine A19. Biochem Biophys Res Commun 87: $1183-1190$

6. Frank BH, Peavy DE, Hooker CS, Duckworth WC (1983) Receptor binding properties of monoiodotyrosyl insulin isomers purified by high performance liquid chromatography. Diabetes 32: 705-711

7. Wilkin TJ (1987) Autoimmunity and autoantibodies in type 1 diabetes. In: Barnett AH (ed) Immunogenetics of insulin dependent diabetes. MTP Press, Lancaster, pp 54-79

8. Koch M, Sodoyez JC, Sodoyez-Goffaux F, Dozio N, Di Silvio LS, Kurtz AB (1989) Is quantitative assessment of insulin-antibodies and autoantibodies feasible. Diabetologia 32: 774-778

9. Kurtz AB, De Silvio L, Bosi E (1988) The determination of detection limits for insulin antibody assays. Diabetologia 31: 395399

10. Hirata Y, Ishizu H, Ouchi N, Motamura S, Abe M, Hara Y, Wagasugi $H$, Tagahashi I, Sakano H, Tanaka M, Kayano H, Kanasaki T (1970) Insulin autoimmunity in a case of spontaneous hypoglycaemia. J Jap Diab Soc 13: 312-320

11. Folling I, Norman N (1972) Hyperglycemia, hypoglycemic attacks, and production of antiinsulin antibodies without previous known immunization. Immunological and functional studies in a patient. Diabetes 21: $814-826$

12. Hirata Y, Tominaga M, Ito JI, Noguchi A (1974) Spontaneous hypoglycemia with insulin autoimmunity in Grave's disease. Ann Intern Med 81: 214-218

13. Goldman J, Baldwin D, Rubenstein AH, Klink DD, Blackard WG, Fisher LK, Roe TF, Schnure JJ (1979) Characterization of circulating insulin and proinsulin-binding antibodies in autoimmune hypoglycemia. J Clin Invest 63: 1050-1059

14. Trenn G, Eysselein V, Mellinghoff HU, Muller R, Benker G, Reinwein D, Federlin K (1986) Clinical and biochemical aspects of the insulin autoimmune syndrome (IAIS). Klin Wochenschr 64: 929-934

15. Sklenar I, Wilkin TJ, Diaz JL, Erb P, Keller U (1987) Spontaneous hypoglycemia associated with autoimmunity specific to human insulin. Diab Care 10: 152-159

16. Blackshear P, Rotner H, Kriaucuinas K, Kahn CR (1983) Reactive hypoglycaemia and insulin autoantibodies in drug induced lupus erythematosis. Ann Int Med 99: 182--184

17. Benson EA, Healey LA, Barron EJ (1985) Insulin antibodies in patients receiving penicillamine. Am J Med 78: 857-860

18. Faguer de Moustier B, Burgard M, Boitard C, Desplanque N, Fanjoux J, Tchobroutsky G (1988) Syndrome hypoglycémique d'origine autoimmune induit par le pyritinol. Diab Metabol 14: 423 429

19. Bergua M, Sole J, Marion G, Perez MC, Recasens A, Casamitjana R, Gomis R (1987) Prevalence of islet cell antibodies, insulin antibodies and hyperglycaemia in 2291 schoolchildren. Diabetologia 30: 724-726

20. Kuglin B, Gries FA, Kolb H (1988) Evidence of IgG autoantibodies against human proinsulin in patients with IDDM before insulin treatment. Diabetes 37: 130-132

21. Sodoyez JC, Sodoyez-Goffaux F, Koch M, Sondag D, Bouillenne C, François-Gérard Ch, Bosi E (1990) Clonally restricted insulin antibodies in a cohort of 2200 healthy blood donors. Diabetologia 33: 719-725

22. Palmer JP, Asplin CM, Clemons P, Lyen K, Tatpati O, Raghu PK, Pacquette TL (1983) Insulin antibodies in insulin dependent diabetics before insulin treatment. Science 222: 1337-1339 
23. Atkinson MA, Maclaren NK, Riley WJ, Winter WE, Fisk DD, Spillar RP (1986) Insulin autoantibodies with markers for insulin dependent diabetes mellitus. Diabetes 35: 894-898

24. Srikanta S, Ricker AT, McCulloch DK, Soeldner JS, Eisenbarth GS, Palmer JP (1986) Autoimmunity to insulin, beta cell dysfunction and development of insulin dependent diabetes mellitus. Diabetes 35: 139-142

25. Arslanian SA, Becker DJ, Rabin B, Atchison R, Eberhardt M, Cavender D, Dorman J, Drash AL (1985) Correlates of insulin antibodies in newly diagnosed children with insulin-dependent diabetes before insulin therapy. Diabetes 34: 926-930

26. Wilkin T, Mirza I, Armitage M, Casey C, Scott-Morgan L (1988) Insulin autoantibody polymorphisms with greater discrimination for diabetes in humans. Diabetologia 31: 670-674

27. Karjalainen J, Knip M, Mustonen A, Ảkerblom HK (1988) Insulin autoantibodies at the clinical manifestation of Type 1 (insulin-dependent) diabetes - a poor predictor of clinical course and antibody response to exogenous insulin. Diabetologia 31: $129-133$

28. Wilkin TJ, Hoskins PJ, Armitage M, Rodier M, Casey C, Diaz JL, Pyke DA, Leslie RDG (1985) Value of insulin antibodies as serum markers for insulin dependent diabetes mellitus. Lancet I: 480-482

29. Thivolet $\mathrm{Ch}$, Beaufrere B, Betuel $\mathrm{H}$, Gebuhrer L, Chatelain $\mathrm{P}$, Durand A, Tourniaire J, François R (1988) Islet cell and insulin autoantibodies in subjects at high risk for development of Type 1 diabetes mellitus: the Lyon family study. Diabetologia 31: 741746

30. Fazekos de St Groth S, Scheidegger D (1980) Production of monoclonal antibodies: strategy and tactics. J Immunol Methods 35: $1-21$

31. Westerwoudt RJ, Blom J, Naipal AM, Van Rond JJ (1983) Improved fusion technique. I. Human umbilical cord serum, a new and potent growth promoter, compared with other B cell and hybridoma activators. J Immunol Methods 62: 59-67

32. Delaunay T, Lovahed J, Bazin H (1990) Elisa measurement of IgG production in mouse hybridoma culture supernatants. J Immunol Methods 131:33-39
33. Koch M, François-Gérard Ch, Sodoyez-Groffaux F, Sodoyez JC (1986) Semi quantitative assessment of antiinsulin total IgG and IgG subclasses in insulin immunised patients using a highly sensitive inmunochemical micromethod. Diabetologia 29: 720-726

34. Markussen J, Larsen UD (1980) The application of HPLC to the analysis of radio-iodinated tracers of glucagon and insulin. In: Brandenburg D, Wollmer A, Gattner HG (eds) Insulin, chemistry, structure and function of insulin and related hormones. De Gruyter, Berlin, pp 161-168

35. Sodoyez JC, Sodoyez-Goffaux F, Guillaume M, Merchie G (1983) Insulin metabolism in normal rats and humans: external detection by a scintillation camera. Science 219: 865-867

36. Scatchard G (1949) The attraction of proteins for small molecules and ions. Ann NY Sci 51 : 660-672

37. Moore WJ (1978) Physical chemistry. Longman Group Limited (eds) William Clowes and Sons, London Colchester Beccles, p 977

38. Tijssen P (1985) Practice and theory of enzyme immunoassays. In: Burdon RH, van Knippenberg PH (eds) Laboratory techniques in biochemistry and molecular biology. Vol 15. Elsevier, Amsterdam, p 549

39. Levy-Marchal C, Bridel MP, Sodoyez-Goffaux F, Koch M, de Beaufort C, Doutreix J, Froment V, Voirin J, Tichet J, Czernichow P, Sodoyez JC (1991) Superiority of radiobinding assay over enzyme linked immunosorbent assay for detection of insulin autoantibodies in newly diagnosed type 1 diabetic patients. Diab Care 14: 61-63

Received: 4 December 1990

and in revised form: 11 March 1991

Dr. J.C.Sodoyez

Department of Endocrinology

CHU-Sart Tilman

B-4000 Liege

Belgium 